\title{
Article \\ An Improved Vermicomposting System Provides More Efficient Wastewater Use of Dairy Farms Using Eisenia fetida
}

\author{
Xue Liu ${ }^{1,2, *}$, Bing Geng ${ }^{1}$, Changxiong $\mathrm{Zhu}^{1}{ }^{1}$, Lianfang $\mathrm{Li}^{1}{ }^{1}$ and Frédéric Francis ${ }^{2, *(D)}$ \\ 1 Agricultural Clean Watershed Research Group, Institute of Environment and Sustainable Development in \\ Agriculture, Chinese Academy of Agricultural Science (CAAS), Beijing 100081, China; \\ gengbing@caas.cn (B.G.); zhucx120@caas.cn (C.Z.); lilianfang@caas.cn (L.L.) \\ 2 Laboratory of Functional and Evolutionary Entomology, Gembloux Agro-Bio Tech, University of Liege, \\ 5030 Gembloux, Belgium \\ * Correspondence: liuxue@caas.cn (X.L.); frederic.francis@uliege.be (F.F.)
}

check for updates

Citation: Liu, X.; Geng, B.; Zhu, C.; Li, L.; Francis, F. An Improved Vermicomposting System Provides More Efficient Wastewater Use of Dairy Farms Using Eisenia fetida. Agronomy 2021, 11, 833. https:// doi.org/10.3390/agronomy11050833

Academic Editor: Mirko Cucina

Received: 11 March 2021

Accepted: 19 April 2021

Published: 23 April 2021

Publisher's Note: MDPI stays neutral with regard to jurisdictional claims in published maps and institutional affiliations.

Copyright: (c) 2021 by the authors. Licensee MDPI, Basel, Switzerland. This article is an open access article distributed under the terms and conditions of the Creative Commons Attribution (CC BY) license (https:// creativecommons.org/licenses/by/ $4.0 /)$.

\begin{abstract}
Dairy cattle farming produces large amounts of wastewater and it causes environmental pollution and eutrophication of rivers, but the nutrients in the waste could be recycled. Here, an improved vermicomposting system was applied to dairy farm wastewater, and wastewater with a nitrogen content of $100 \mathrm{mg} / \mathrm{L}$ and $200 \mathrm{mg} / \mathrm{L}$ tested with different combinations of organic substrates such as cow manure and rice straw in rural solid waste. Results showed that earthworms could continuously grow, wastewater $(\mathrm{N} 100 \mathrm{mg} / \mathrm{L})$ mixed with rice straw corresponding to the most significant gained weight for Eisenia fetida earthworms (2.38 to 9.12-fold), and the earthworms' weight was positively correlated with the $\mathrm{C} / \mathrm{N}$ ratio, organic matter content, and $\mathrm{pH}$. Compared to the initial state, the system significantly changed physicochemical parameters in nutrients, such as the percentages of total nitrogen, phosphorous, and potassium, which were found to increase in vermicomposting while organic matter content, $\mathrm{C} / \mathrm{N}$ ratio, and cellulose declined as a function of the vermicomposting period, and the final vermicompost was better for the absorption of plants. These results suggest that continuous wastewater addition improved the effective transformation of organic waste to allow valorizing a broad range of organic residues, and avoid the risk of environmental pollution in dairy cattle farming.
\end{abstract}

Keywords: wastewater; rice straw; cow manure; Eisenia fetida; biological parameters; vermicomposting; waste management; germination; microbial community

\section{Introduction}

Eutrophication of lakes and rivers is becoming a more serious problem that threatens the safety of human drinking water. Livestock farming constitutes a large proportion of the agricultural non-point source pollutants that cause eutrophication, and China's first pollution-source census demonstrates that dairy cattle farming may be the largest contributor to the problem. Specifically, dairy cattle farming produces 2.2 times more pollutants than non-dairy cattle farming and 15.5 times more than swine farming [1]. The increasing demand for milk from growing human populations requires an innovative solution to mitigate the impact of dairy cattle farms on their surrounding environments.

Backyard breeders and farmers often discard waste directly into surrounding environment, and the current procedures of large-scale operations are costly and somewhat inefficient at removing the organic compounds that contribute to eutrophication. Largescale livestock farms commonly use anaerobic digestion or aerobic digestion reactors [2]. Up-flow anaerobic sludge blanket (UASB) reactors are routinely used in centralized sewage collection and treatment $[3,4]$, but anaerobic digestion does not remove nitrogen or phosphorus from wastewater. The remaining biogas slurry and residue caused by this secondary pollution is anaerobic, and then inaccessible as crop fertilizer [5]. Activated sludge systems are typically used for aerobic digestion [6,7], but are associated with the production of large 
amounts of sludge that also needs to be treated. The remaining sludge does not precipitate well due to its high moisture content. Moreover, it has a propensity to expand and float. The use of these two centralized digestion systems has high input costs, high energy consumption, and there are other more actually technical skills for smaller operations.

Using earthworms to treat solid organic waste (i.e., vermicomposting) provides a cheaper and easier alternative to other waste treatment methods [8]. In vermicomposting, worms digest and transform organic waste, also producing a compost to be used in crops for fertilization. Indeed the earthworm metabolic activity during this process enhances the level of nutrients in the transformed wastes [9]. Finally, vermicomposting creates more available nutrients per weight than the original organic substrate before earthworm action, converting organic wastes into excellent bio-fertilizers with abundant humic-like compounds and diverse probiotics that are helpful for agricultural use [10]. Therefore, vermicomposting can facilitate plant growth [11], and unlike pure animal manure, it is an excellent substrate for growing seedlings. Vermicomposting applications correspond to the improvement of conventional composting by adding earthworms to provide a better organic waste stabilization process [12]. Compared to conventional compost, vermicomposting contains higher levels of soluble nutrients and higher quality organic matter [13]. It is a bio-oxidative process in which earthworms and microbes, along with other degradable communities, interact and accelerate the decomposition process of organic waste [14].

Vermicomposting is being utilized within commercially available on-site waste treatment systems; however, there are few reported studies that have examined this medium for the purpose of wastewater treatment [15].

The objective of this study on the improved vermicomposting system was to examine the effects of high nitrogen and carbon contents in the waste liquid from dairy farm wastewater on vermicomposting. The original contributions of this study are that there was a clear difference in evaporation rates of the materials with and without earthworms, and less moisture in the manure added earthworms than in the manure with no earthworms [16]. According to the characteristics of high nitrogen content and high carbon content in the waste liquid of dairy farm wastewater, the continuous addition of wastewater to support the loss of water and maintain the humidity of the system to facilitate the earthworm activities in vermicomposting, in keeping with the sustainable environmental requirements of earthworms' growth. The metabolism of earthworms transforms the nutrients of wastewater, cow dung, and straw into earthworm and earthworm manure with high economic value, achieving the goal of resource utilization and zero release of rural organic wastes. In addition, no after-treatment by-products are generated by achieving the aim of minimizing pollution. Nitrogen loss caused by high temperature composting and air pollution caused by incineration of agricultural organic wastes can be avoided, and this process will not produce after treatment by-products, to achieve the purpose of eliminating pollution.

\section{Materials and Methods}

\subsection{Dairy Farm Waste Collection and Worm Rearing}

Rice straw and cow manure were collected from a dairy farm in Yanqing county of Beijing in China; we selected the rice straw harvested in current autumn and fresh manure and wastewater. Young earthworms (Eisenia fetida, (Savigny, 1826)) were mass-reared on fresh cow manure in the Institute of Environment and Sustainable Development in Agriculture, Chinese Academy of Agricultural Sciences (CAAS). Fresh cow manure was homogenized and shade-dried in the lab for 2 weeks. Rice straw was cut off to a length of about $1.2 \mathrm{~cm}$. Dairy farm wastewater was diluted with aseptic water and compounded to total nitrogen $100 \mathrm{mg} / \mathrm{L}$ and $200 \mathrm{mg} / \mathrm{L}$ (pH 7.70). Plastic circular containers with 4 holes in the bottoms were used as vermireactors $(13.0 \mathrm{~cm} \times 9.0 \mathrm{~cm} \times 10.0 \mathrm{~cm})$ and the bottoms were sealed with insect netting (mesh size $5 \mathrm{~mm}$ ). 


\subsection{Vermicomposting Experimental Set-Up}

Two dairy farm waste materials (wastewater and cow manure) and rice straw were used in the experiment. Combinations of three rates of cow manure in rice straw $(0,20$ or $40 \%$ called $\mathrm{M}_{0}, \mathrm{M}_{20}$, and $\mathrm{M}_{40}$ respectively) with two levels of nitrogen content in wastewater (total nitrogen of 100 or $200 \mathrm{mg} / \mathrm{L}$ called $\mathrm{N}_{1}$ and $\mathrm{N}_{2}$ respectively) corresponding to six treatments were tested (namely $\mathrm{M}_{0} \mathrm{~N}_{1}, \mathrm{M}_{20} \mathrm{~N}_{1}, \mathrm{M}_{40} \mathrm{~N}_{1}, \mathrm{M}_{0} \mathrm{~N}_{2}, \mathrm{M}_{20} \mathrm{~N}_{2}$, and $\mathrm{M}_{40} \mathrm{~N}_{2}$ ). Each treatment was tested in triplicate, resulting in a total of 126 containers. Twenty non-clitella worms ( $275 \mathrm{mg})$ were selected from the stock rearing and added to each container on the 2nd day. Dairy farm wastewater was added to the system every 3 days to supply the needed amount to avoid desiccation. To measure the digested volume of the wastewater, we measured the added and outflow wastewater from the containers. The moisture content was maintained at $60-80 \%$ throughout the vermicomposting period. The containers were kept at $20^{\circ} \mathrm{C}$ in the lab. The tests were conducted for 60 days. No rice straw or cow manure was added during this vermicomposting period.

\subsection{The Biological Parameters of Earthworms}

Over the 60 days of the vermicomposting process, earthworm abundance and biomass were measured every 10 days. Worms were separated by hand, counted, and weighed manually (live weight). Before weighing, worms were washed in distilled water and dried on filter paper. Worms were quickly weighed and returned to their containers to prevent desiccation.

\subsection{Physicochemical Parameter Analysis of the Vermicomposting Process and Germination tests}

Organic matter (OM), total Kjeldahl nitrogen (TKN), total phosphorus (TP), total potassium (TK), cellulose, $\mathrm{pH}$, and $\mathrm{C} / \mathrm{N}$ ratio were measured in the initial and the final mixtures [17-19]. The $\mathrm{pH}$ was determined in a 1:10 $(w / v)$ aqueous solution (deionized water) with a digital $\mathrm{pH}$ meter (Mettler Toledo). The seed germination index was determined at the initial and final points of the improved vermicomposting system using previously described methods [20,21].

\subsection{Microbial Diversity Analysis}

\subsubsection{Sample Collection}

$R_{0}$ and $R_{60}$ were the same treatments as $M_{0} N_{2}$ at 0 and 60 days, respectively, while $\mathrm{CK}_{0}$ and $\mathrm{CK}_{60}$ were the same treatments as $\mathrm{M}_{0} \mathrm{~N}_{2}$ at 0 and 60 days, respectively, but without earthworms (Table 1).

Table 1. Consumption of wastewater parameters in the improved vermicomposting system until 60th day.

\begin{tabular}{lcccccc}
\hline \multirow{2}{*}{ Parameter $^{\mathrm{a}}$} & \multicolumn{7}{c}{ Treatments } \\
\cline { 2 - 7 } & $\mathbf{M}_{\mathbf{0}} \mathbf{N}_{\mathbf{1}}$ & $\mathbf{M}_{\mathbf{0}} \mathbf{N}_{\mathbf{2}}$ & $\mathbf{M}_{\mathbf{2 0}} \mathbf{N}_{\mathbf{1}}$ & $\mathbf{M}_{\mathbf{4 0}} \mathbf{N}_{\mathbf{1}}$ & $\mathbf{M}_{\mathbf{2 0}} \mathbf{N}_{\mathbf{2}}$ & $\mathbf{M}_{\mathbf{4 0}} \mathbf{N}_{\mathbf{2}}$ \\
\hline${\text { Volume }(\mathrm{mL})^{\mathrm{b}}}^{\mathrm{T}}$ & $980 \mathrm{a}$ & $980 \mathrm{a}$ & $895 \mathrm{~b}$ & $895 \mathrm{~b}$ & $770 \mathrm{c}$ & $770 \mathrm{c}$ \\
${\text { Total nitrogen }(\mathrm{mg})^{\mathrm{c}}}$ & $98 \mathrm{~d}$ & $196 \mathrm{a}$ & $89.5 \mathrm{e}$ & $89.5 \mathrm{e}$ & $144 \mathrm{c}$ & $154 \mathrm{~b}$ \\
\hline
\end{tabular}

${ }^{a}$ For each parameter (see text for details), differences among treatments were determined by Tukey's test. Different letters in arrow are significant at $p<0.05$ (Tukey's test). ${ }^{\mathrm{b}}$ The total volume of the added wastewater into the improved vermicomposting system because that the dairy farm wastewater was added to the system every 3 days to supply the needed amount to avoid desiccation. ${ }^{c}$ The total nitrogen of the added wastewater into the improved vermicomposting system.

\subsubsection{DNA Extraction and PCR Amplification}

Genomic DNA was extracted from solid samples using the E.Z.N.A. Stool DNA Kit (Omega Bio-Tek, Norcross, GA, USA) according to the manufacturer's instructions. The quality of the extracted DNA was checked by $1 \%$ agarose gel electrophoresis and spectrophotometry (optical density at a $260 \mathrm{~nm} / 280 \mathrm{~nm}$ ratio). All extracted DNA samples were stored at 
$-20^{\circ} \mathrm{C}$ for further analysis. The V3-V4 hypervariable regions of the $16 \mathrm{~S}$ rRNA gene were subjected to high-throughput sequencing by Beijing All we gene Tech (Beijing, China) using the Illumina MiSeq PE300 sequencing platform (Illumina, CA, USA). The V3-V4 region of the bacteria $16 \mathrm{~S}$ rRNA gene were amplified with forward 336F (5'-GTACTCCTACGGGAGGCAGCA$\left.3^{\prime}\right)$ and reverse 806R (5'-GTGGACTACHVGGGTWTCTAAT-3') universal primers. These primers contain an 8-nucleotide long barcode sequence that is unique to each sample. PCR (Polymerase Chain Reaction) was performed as follows: $95^{\circ} \mathrm{C}$ for $5 \mathrm{~min}, 28$ cycles at $95{ }^{\circ} \mathrm{C}$ for $45 \mathrm{~s}, 50{ }^{\circ} \mathrm{C}$ for $50 \mathrm{~s}$, and $72{ }^{\circ} \mathrm{C}$ for $45 \mathrm{~s}$, with a final extension of $72{ }^{\circ} \mathrm{C}$ for $10 \mathrm{~min}$. PCR reactions were performed in triplicate with $25-\mu \mathrm{L}$ mixtures containing $2.5 \mu \mathrm{L}$ of $10 \times$ Pyrobest buffer, $2 \mu \mathrm{L}$ of $2.5 \mathrm{mM}$ dNTPs, $1 \mu \mathrm{L}$ of each primer $(10 \mu \mathrm{M}), 0.4 \mathrm{U}$ of Pyrobest DNA polymerase (TaKaRa), and $15 \mathrm{ng}$ of template DNA. The amplicon mixture was applied to the MiSeq Genome Sequencer (Illumina, San Diego, CA, USA).

\subsubsection{Illumina MiSeq Sequencing}

Amplicons were extracted from 2\% agarose gels and purified using the Axy Prep DNA Gel Extraction Kit (Axygen Biosciences, Union City, CA, USA) according to the manufacturer's instructions and quantified using Quanti Fluor ${ }^{\mathrm{TM}}$-ST (Promega, Fitchburg, WI, USA). Purified amplicons were pooled in equimolar concentrations and paired-end sequenced $(2 \times 300)$ on an Illumina MiSeq platform according to standard protocols.

\subsubsection{Processing of Sequencing Data}

The extraction of high-quality sequences was first performed with the QIIME package (v1.2.1; Quantitative Insights Into Microbial Ecology; J Gregory caporaso, University of Colorado, Boulder, CO, USA). Raw sequences were selected based on sequence length, quality, primer, and tag. The raw sequences were selected, and the low-quality sequences were removed based on the following criteria: (i) raw reads were shorter than 110 nucleotides; (ii) 300-bp reads were truncated at any site receiving an average quality score $<20$ over a 50-bp sliding window (the truncated reads that were shorter than $50 \mathrm{bp}$ were discarded); (iii) exact barcode matching, 2 nucleotide mismatches in primer matching (reads containing ambiguous characters were removed); and (iv) only sequences that overlapped more than $10 \mathrm{bp}$ were assembled according to their overlap sequence (reads that could not be assembled were discarded).

The unique sequence set was classified into operational taxonomic units (OTUs) under the threshold of $97 \%$ identity using UCLUST. Chimeric sequences were identified and removed using Usearch (v8.0.1623). The taxonomy of each 16S rRNA gene sequence was analyzed by UCLUST against the Silva119 $16 \mathrm{~S}$ rRNA database using a confidence threshold of $90 \%$.

\subsection{Statistical Analysis}

All of the reported data were the means of three replicates. One-way analysis of variance (ANOVA) was used to detect significant differences among treatments. Independent Tukey's tests were also performed to evaluate the distribution of the data sets. Statistical analyses were performed using the SPSS statistical package (Version 13.0; SPSS Inc., Chicago, IL, USA). Unless otherwise indicated, $p<0.05$ was selected to indicate statistical significance.

\section{Results and Discussion}

\subsection{Consumption of Dairy Farm Wastewater during Vermicomposting}

After the preliminary experiment, the total nitrogen concentration of the dairy farm wastewater was set at 100 and $200 \mathrm{mg} / \mathrm{L}$. These two concentrations are higher than the standard for pollutant discharge issued by the national livestock breeding industry. In our study, the amount of wastewater input was closed to the amount of water evaporated by the system. The amount of wastewater consumed in the $\mathrm{M}_{0} \mathrm{~N}_{1}$ and $\mathrm{M}_{0} \mathrm{~N}_{2}$ was the largest (Table 1). In these treatments, all of the fillers were straw and explained this result. The 
crushed stalks were short and rod-shaped, with gaps between them, making it easier for the moisture to drain. Therefore, more wastewater was needed to maintain the system's humidity. In the mixture of other groups that contained cow manure, the latter was crushed into powder, the crevices between pieces of straw were filled, and the water was more easily retained. The rate of water loss was relatively low, the system moisturizing effect was better, and liquid waste did not need to be added as frequently.

In each $100 \mathrm{~g}$ improved vermicomposting system, the volume of dairy farm wastewater consumed by $\mathrm{M}_{0} \mathrm{~N}_{1}$ and $\mathrm{M}_{0} \mathrm{~N}_{2}$ was similar. $\mathrm{M}_{0} \mathrm{~N}_{2}$ consumed $196 \mathrm{mg}$ of $\mathrm{TKN}$ and $\mathrm{M}_{0} \mathrm{~N}_{1}$ consumed $98 \mathrm{mg}$. In terms of total nitrogen consumption, $\mathrm{M}_{0} \mathrm{~N}_{2}$ was a more suitable treatment system for dairy farm wastewater. This study provides information on how the nutrient components of wastewater affect the ability of earthworms to grow, thereby absorbing and transforming organic waste into high-value earthworms and earthworm manure. Vermicomposting using these methods discharge no wastewater, achieving the goal of zero pollutants.

\subsection{Earthworm Weight Changes during Vermicomposting}

After 10 days, the average weights of all earthworms, except for the $\mathrm{M}_{0} \mathrm{~N}_{2}$ conditions, increased (Figure 1). After 20 days, all treatments had continued positive effect on the average earthworm growing. $\operatorname{InM}_{20} \mathrm{~N}_{1}, \mathrm{M}_{40} \mathrm{~N}_{1}, \mathrm{M}_{20} \mathrm{~N}_{2}$, and $\mathrm{M}_{40} \mathrm{~N}_{2}$ containing cow manure, significant higher weight gain were observed when compared to earthworms in $\mathrm{M}_{0} \mathrm{~N}_{1}$ and $\mathrm{M}_{0} \mathrm{~N}_{2}$, which had only rice straw. After 30 days, the earthworm's average weight in $\mathrm{M}_{20} \mathrm{~N}_{1}, \mathrm{M}_{40} \mathrm{~N}_{1}, \mathrm{M}_{20} \mathrm{~N}_{2}$, and $\mathrm{M}_{40} \mathrm{~N}_{2}$ declined, while the ones in $\mathrm{M}_{0} \mathrm{~N}_{1}$ and $\mathrm{M}_{0} \mathrm{~N}_{2}$ increased. At day 60, the change in the latter was significantly higher than the ones in $\mathrm{M}_{20} \mathrm{~N}_{1}, \mathrm{M}_{40} \mathrm{~N}_{1}$, $\mathrm{M}_{20} \mathrm{~N}_{2}$, and $\mathrm{M}_{40} \mathrm{~N}_{2}$. The average weight change of $\mathrm{M}_{0} \mathrm{~N}_{1}$ was 2.4 times that of $\mathrm{M}_{20} \mathrm{~N}_{1}$, and 9.1 times that of $\mathrm{M}_{40} \mathrm{~N}_{1}$. The average weight change of $\mathrm{M}_{0} \mathrm{~N}_{2}$ was 2.1 times that of $\mathrm{M}_{20} \mathrm{~N}_{2}$ and 1.7 times that of $\mathrm{M}_{40} \mathrm{~N}_{2}$ (Table 1).

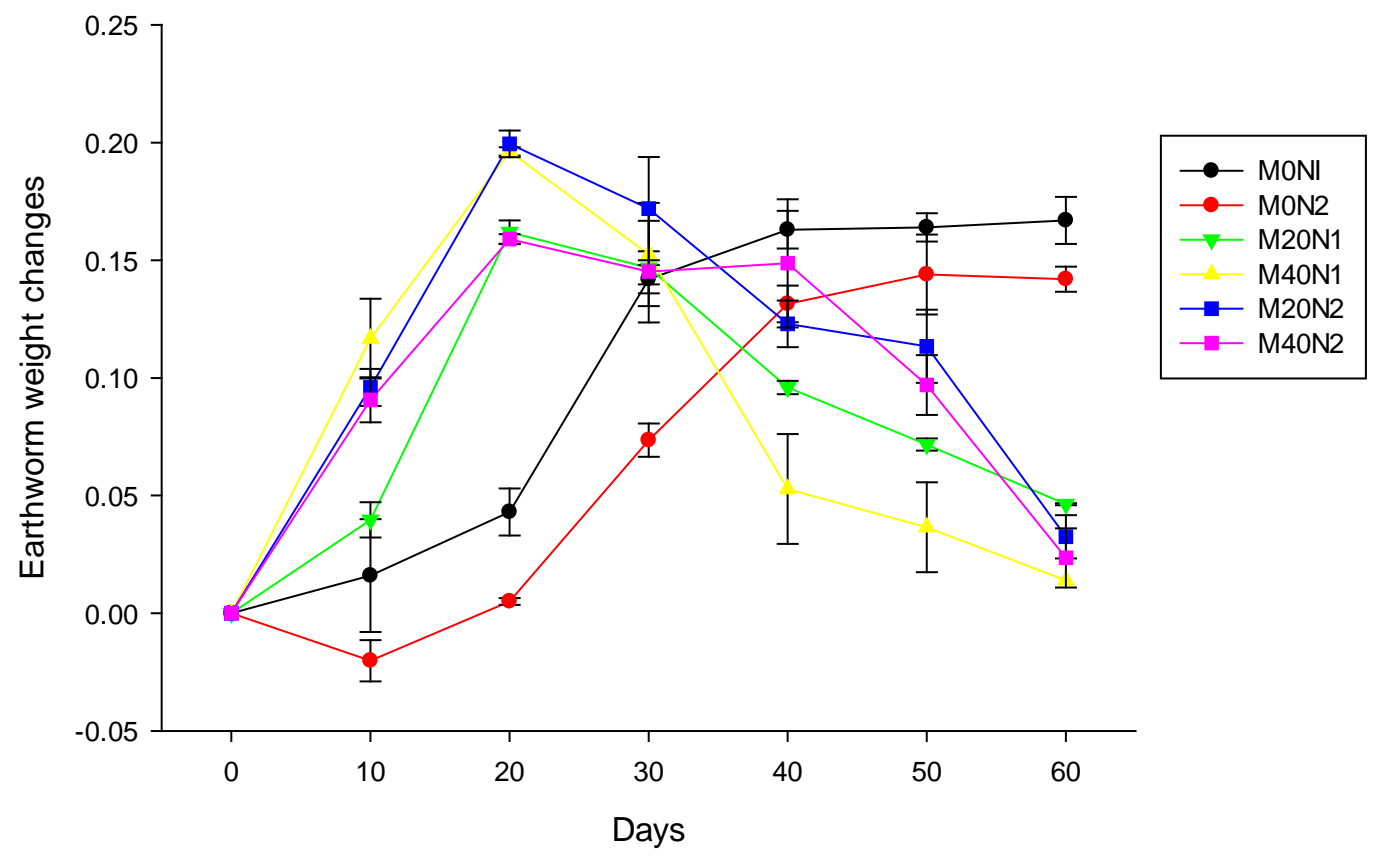

Figure 1. Evolution of Eisenia fetida weight according to different proposed diets (in g per worm on 60 day durations).

Earthworms utilize nutrients from different sources to supply their growth needs [22]. The weight change of earthworms was significantly correlated with the $\mathrm{C} / \mathrm{N}$ ratio.

Dairy wastewater continually supplemented nitrogen, reducing the $\mathrm{C} / \mathrm{N}$ ratio of all treatments gradually. The $\mathrm{M}_{0} \mathrm{~N}_{1}$ and $\mathrm{M}_{0} \mathrm{~N}_{2}$ conditions became more and more suitable for earthworm growth as this supplementation process continued. High nitrogen can exceed the tolerance limit of earthworms, resulting in slow growth or death [23]. Indeed, 
at day 20 of the experiment, because of the large amounts of nitrogen in cow manure of $\mathrm{M}_{20} \mathrm{~N}_{1}, \mathrm{M}_{40} \mathrm{~N}_{1}, \mathrm{M}_{20} \mathrm{~N}_{2}$, and $\mathrm{M}_{40} \mathrm{~N}_{2}$, the additional dairy wastewater added nitrogen into the mixture, resulting in the increasing nitrogen content, and high nitrogen is toxic to earthworms, so the weight of earthworms began to decrease.

\subsection{The Response of Physicochemical Parameters during the Vermicomposting Period}

After 60 days, the black color and uniformly disintegrated structure of the mixtures indicated the presence of worm activity [24]. TKN, TP, and TK increased in all of the tests under different treatments after the vermicomposting (Figure 2). The difference between various mixtures was statistically significant (ANOVA, $p<0.05$ ) at the end of the process. Traditionally, TKN, TP, TK, organic matter content, and the $\mathrm{C} / \mathrm{N}$ ratio are considered indicators of decomposition and compost quality [25]. Then, the treatments inoculated with earthworms were more decomposed, and the fillers after vermicomposting were more preferable for bio-organic fertilizer manufacturing [26].

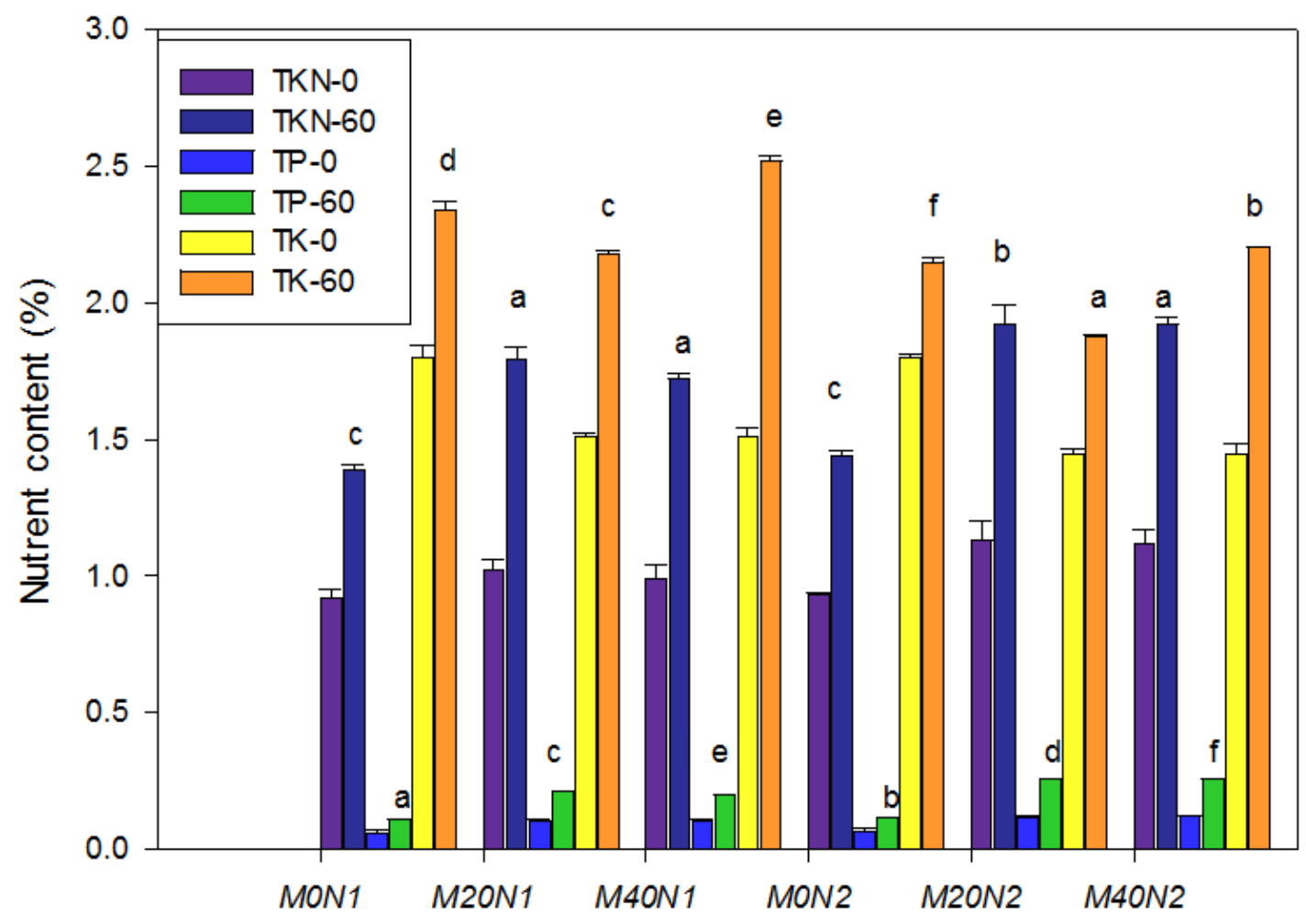

Figure 2. Total Kjeldahl nitrogen (TKN)\%, total phosphorus (TP) \%, and total potassium (TK) $\%$ in different treatments on days 0 and 60 of the experiment. (N-0:TKN\% at 0 day; N-60:TKN\% at 60 day; TP-0:TP\% at 0 day; TP-60:TP\% at 60 day; TK-0:TK\% at 0 day; TK-60:TK\% at 60 day). Compared the difference values of TKN-60 to TKN-0, TP-60 to TP-0, TK-60 to TK-0 in different treatments, the different letters of $a, b, c, d$ were marked on the bar to indicate the significantly different which were determined by Tukey's test $(p<0.05)$.

In the test, there was a $51.1 \%$ increase in TKN for $\mathrm{M}_{0} \mathrm{~N}_{1}$, a $75.5 \%$ increase for $\mathrm{M}_{20} \mathrm{~N}_{1}$, and a $69.9 \%$ increase for $\mathrm{M}_{40} \mathrm{~N}_{1}$ compared to the initial level. There was a $54.8 \%$ increase in TKN form $\mathrm{M}_{0} \mathrm{~N}_{2}$, a $73.7 \%$ increase for $\mathrm{M}_{20} \mathrm{~N}_{2}$, and a $71.4 \%$ increase for $\mathrm{M}_{40} \mathrm{~N}_{2}$ compared to the initial level (Figure 2). The rate of increase in TKN was higher than $50 \%$, and the mixtures with $20 \%$ of cow manure had the highest TKN content. The TKN of $20 \%$ cow manure and $40 \%$ manure were $1.7 \%$ to $1.9 \%$ at the 60 th day, which were higher than TKN of only-cow manure which was about $1.6 \%$ at the 60 th day (with Eisenia fetida, no wastewater), the TKN of only-straw were $1.3 \%$ and $1.4 \%$. TKN of treatments ranged between $1.4 \%$ and $1.9 \%$ at 60 th day, and values were similar to those already reported. The TKN content ranging from $1.2 \%$ to $1.7 \%$ for vermicompost of paper cattle manure, mill sludge, and dairy sludge were reported [27]. Vermicompost of bilsolids mixed with paper mulch contained 
$1.7 \%$ [28]. But whereas the range reported by values ranging between $1.9 \%$ to $3.7 \%$ for different types of waste [29]. It indicated that the improved vermicomposting system also had a great impact on nitrogen transformations in the manure, by enhancing nitrogen mineralization, so that mineral nitrogen was retained.

The same trend was observed for TP and TK (Figure 2). There was a $76.4 \%$ increase in TP for $\mathrm{M}_{0} \mathrm{~N}_{1}$, a $107.1 \%$ increase for $\mathrm{M}_{20} \mathrm{~N}_{1}$, and a $115.3 \%$ increase for $\mathrm{M}_{40} \mathrm{~N}_{1}$. There was a $73.1 \%$ increase in TP for $\mathrm{M}_{0} \mathrm{~N}_{2}$, a $89.1 \%$ increase for $\mathrm{M}_{20} \mathrm{~N}_{2}$, and a $111.3 \%$ increase for $\mathrm{M}_{40} \mathrm{~N}_{2}$. Then, the largest increases in TP which group with $40 \%$ cow manure were observed in $\mathrm{M}_{40} \mathrm{~N}_{1}$ and $\mathrm{M}_{40} \mathrm{~N}_{2}$ (ANOVA, $p<0.05$ ), the lowest increases in TP which group with rice straw-only were observed in $\mathrm{M}_{0} \mathrm{~N}_{1}$ and $\mathrm{M}_{0} \mathrm{~N}_{2}$ (ANOVA, $p<0.05$ ). There was a $30.0 \%$ increase in TK for $\mathrm{M}_{0} \mathrm{~N}_{1}$, a $43.8 \%$ increase for $\mathrm{M}_{20} \mathrm{~N}_{1}$, and a $29.9 \%$ increase for $\mathrm{M}_{40} \mathrm{~N}_{1}$. There was a $19.5 \%$ increase in TK for $\mathrm{M}_{0} \mathrm{~N}_{2}$, a $66.4 \%$ increase for $\mathrm{M}_{20} \mathrm{~N}_{2}$, and a $52.5 \%$ increase for $\mathrm{M}_{40} \mathrm{~N}_{2}$. Therefore, the $\mathrm{M}_{20} \mathrm{~N}_{1}$ and $\mathrm{M}_{20} \mathrm{~N}_{2}$ treatments, which contained $20 \%$ cow manure, showed the largest increase in TK concentration. Overall, the treatments with earthworms had more nutrients after vermicomposting. During the present investigation, the TP concentration varied from $1.1 \%$ to $2.6 \%$ and the TK concentration varied from $18.8 \%$ to $25.2 \%$ at the 60 th day, in comparison with recommended standards the TP and TK were found higher in all the samples [30].

Organic matter content decreased in all treatments after vermicomposting (Figure 3A), the difference among mixtures was statistically significant (ANOVA, $p<0.05$ ). In comparison to the initial values, there were $5.3 \%, 19.4 \%$, and $22.1 \%$ decreases for $\mathrm{M}_{0} \mathrm{~N}_{1}, \mathrm{M}_{20} \mathrm{~N}_{1}$, and $\mathrm{M}_{40} \mathrm{~N}_{1}$, respectively, and $8.8 \%, 15.3 \%$, and $21.6 \%$ decreases for $\mathrm{M}_{0} \mathrm{~N}_{2}, \mathrm{M}_{20} \mathrm{~N}_{2}$, and $\mathrm{M}_{40} \mathrm{~N}_{2}$. The organic matter content varied from $51.3 \%$ to $64.4 \%$ at the 60 th day, which were higher than $45 \%$ in the National Organic Fertilizers Standard [31]. The reduction in the organic matter content could be attributed to the rapid decomposition and consumption of the organic materials by earthworms and microorganisms present in their guts [32].

In our experiment, the initial $C / N$ ratio of $\mathrm{M}_{0} \mathrm{~N}_{1}$ and $\mathrm{M}_{0} \mathrm{~N}_{2}$ with only rice straw was significantly higher than that in $\mathrm{M}_{20} \mathrm{~N}_{1}, \mathrm{M}_{40} \mathrm{~N}_{1}, \mathrm{M}_{20} \mathrm{~N}_{2}$, and $\mathrm{M}_{40} \mathrm{~N}_{2}$, which also contained cow manure (Figure 3 ). The $\mathrm{C} / \mathrm{N}$ ratio significantly decreased among the different mixtures at the end of the experiments (Figure 3B). Decreases of $37.5 \%, 54.4 \%$, and $54.4 \%$ in C/N were observed in $\mathrm{M}_{0} \mathrm{~N}_{1}, \mathrm{M}_{20} \mathrm{~N}_{1}$, and $\mathrm{M}_{40} \mathrm{~N}_{1}$, and decreases of around $41.4 \%, 51.2 \%$, and $54.4 \%$ in $\mathrm{M}_{0} \mathrm{~N}_{2}, \mathrm{M}_{20} \mathrm{~N}_{2}$, and $\mathrm{M}_{40} \mathrm{~N}_{2}$. After 60 days, the $\mathrm{C} / \mathrm{N}$ ratios of $\mathrm{M}_{0} \mathrm{~N}_{1}$ and $\mathrm{M}_{0} \mathrm{~N}_{2}$ were 26.9 and 25.0, the $C / N$ ratios of $M_{20} N_{1}$ and $M_{20} N_{2}$ were 17.3 and 19.1, and the $C / N$ ratios of $\mathrm{M}_{40} \mathrm{~N}_{1}$ and $\mathrm{M}_{40} \mathrm{~N}_{2}$ were 15.5 and 15.6. Overall the $\mathrm{C} / \mathrm{N}$ ratios of biosolids in our improved vermicomposting system after treatment were positively correlated with those before. The $\mathrm{C} / \mathrm{N}$ ratios of the rice straw-only treatment groups were all above 25 , in keeping with reports in the literature indicating that a $\mathrm{C} / \mathrm{N}$ ratio of 25 resulted in the highest and the best fertilizer value of the product [33]. The results of this study revealed that rice straw-only treatments can be used continuously for long time periods and are more capable of eliminating pollutants from dairy farm wastewater.

At the end of the experiment, the cellulose contents of $\mathrm{M}_{0} \mathrm{~N}_{1}$ and $\mathrm{M}_{0} \mathrm{~N}_{2}$ had decreased by $42.1 \%$ and $38.3 \%$, respectively, those of $\mathrm{M}_{20} \mathrm{~N}_{1}$ and $\mathrm{M}_{20} \mathrm{~N}_{2}$ had decreased by $31.0 \%$ and $23.7 \%$ respectively, and those of $\mathrm{M}_{40} \mathrm{~N}_{1}$ and $\mathrm{M}_{40} \mathrm{~N}_{2}$ had decreased by $15.5 \%$ and $26.6 \%$ respectively (Figure $3 \mathrm{C}$ ). This is concordant with the observation that the largest decrease in cellulose content was in the straw-only treatment. Comparing the results of different concentrations of wastewater in the same treatment, cellulose degraded faster in $100 \mathrm{mg} / \mathrm{L}$ (TKN) than in $200 \mathrm{mg} / \mathrm{L}$ (TKN). This may be because the addition of mild nitrogen which has a lower and mild concentration of nitrogen is more conducive to the metabolism and growth of earthworms, thereby promoting the degradation of cellulose.

The initial $\mathrm{pH}$ values of $\mathrm{M}_{0} \mathrm{~N}_{1}$ and $\mathrm{M}_{0} \mathrm{~N}_{2}, \mathrm{M}_{20} \mathrm{~N}_{1}$ and $\mathrm{M}_{20} \mathrm{~N}_{2}$, and $\mathrm{M}_{40} \mathrm{~N}_{1}$ and $\mathrm{M}_{40} \mathrm{~N}_{2}$ were 8.1, 8.6, and 8.9, respectively. At the end of the experiment, the $\mathrm{pH}$ values of $\mathrm{M}_{0} \mathrm{~N}_{1}$ and $\mathrm{M}_{0} \mathrm{~N}_{2}$ were 9.0and 9.0, those of $\mathrm{M}_{20} \mathrm{~N}_{1}$ and $\mathrm{M}_{20} \mathrm{~N}_{2}$ were 9.1 and 8.9, and those of $\mathrm{M}_{40} \mathrm{~N}_{1}$ and $\mathrm{M}_{40} \mathrm{~N}_{2}$ were 9.0 and 9.0, respectively (Figure 3D). The $\mathrm{pH}$ of all the treated matrix was about 9.0 , and the activity of earthworms changed the $\mathrm{pH}$ of the mixture. Vermicomposting 
can change the $\mathrm{pH}$ of different sources of substances through the decomposition of organic matter into inorganic matter [34]. The $\mathrm{pH}$ of the vermicomposting process is also strongly correlated with ammonia volatilization [35]. In this study, the continuous supplement of dairy farm wastewater increased the nitrogen content of the improved vermicomposting system, and then the ammonia content due to gaseous losses was replenished. Therefore, the differences in $\mathrm{pH}$ resulting from the addition of wastewater were significant over the period of the experiment.
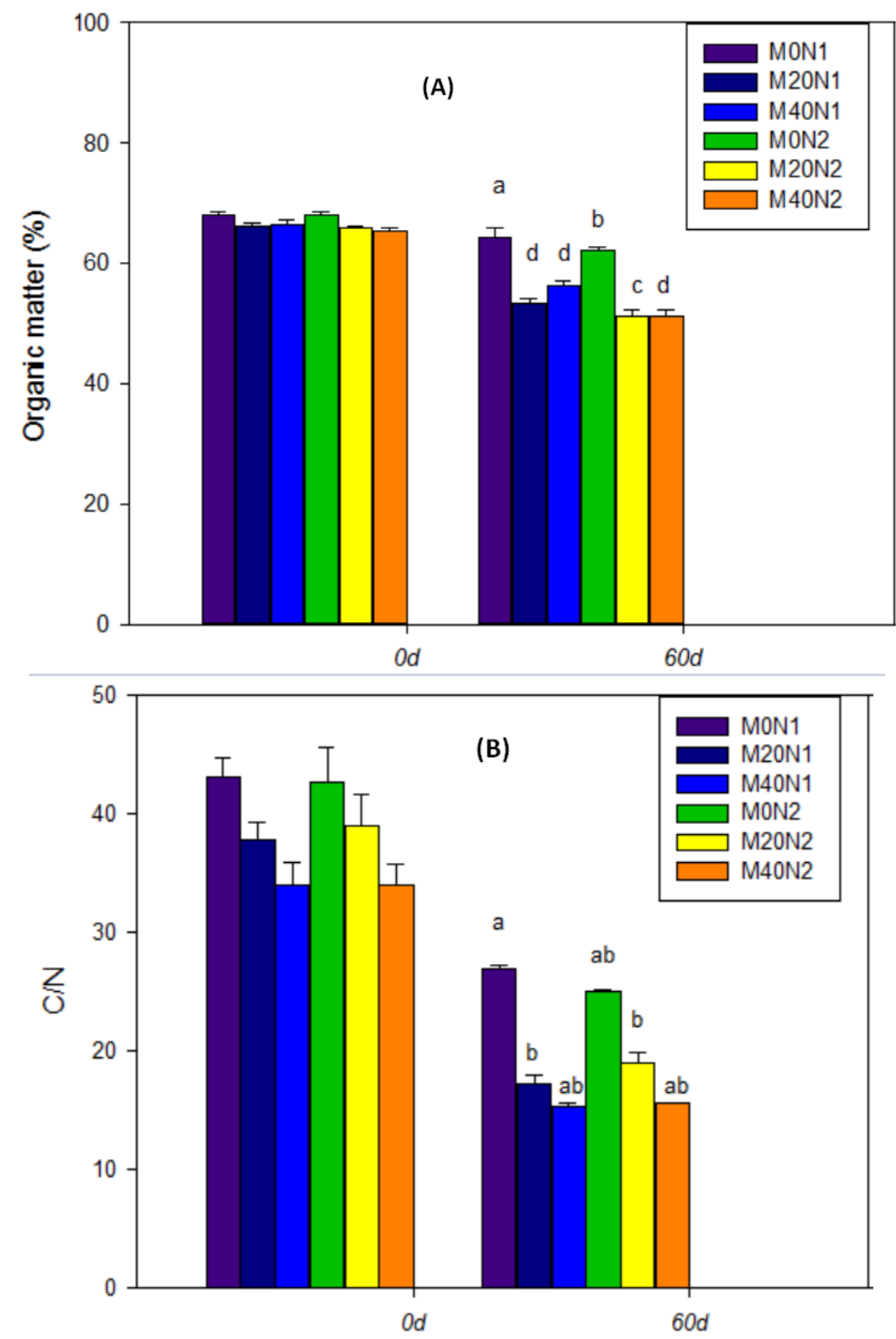

Figure 3. Cont. 

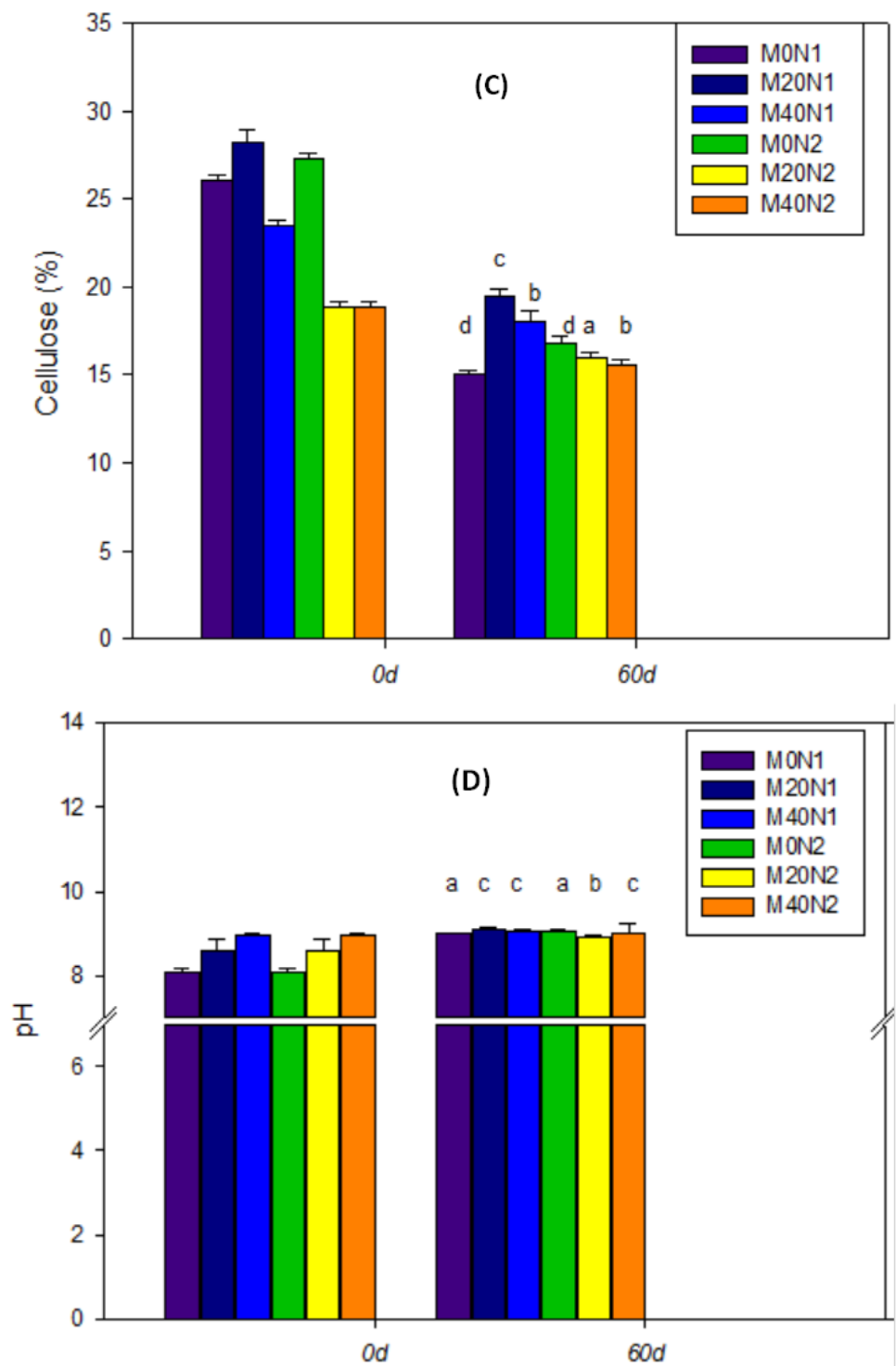

Figure 3. Changes in the physicochemical properties of the different treatments at 0 and 60 days. Comparing the difference values of orgnic matter of 60 day to 0 day (A), $\mathrm{C} / \mathrm{N}$ ratio of 60 day to 0 day (B), cellulose of 60 day to 0 day (C), $\mathrm{pH}$ value of 60 day to 0 day (D) in different treatments; different letters in arrows are significant at $p<0.05$ (Tukey's test).

\subsection{Phytotoxicity Test}

Immature compost products may have toxic effects on seed germination and seedling growth. We used the germination index to measure the physiological toxicity and maturity of earthworm composting products. Intuitively, when the seed germination coefficient is greater than $50 \%$, the composting is considered to have reached maturity [36]. In the study (Table 2), the germination index of the six tests were all higher than $60 \%$, which demonstrated the improved vermicomposting system form could increase plant productivity. The germination index of $\mathrm{M}_{0} \mathrm{~N}_{1}$ and $\mathrm{M}_{0} \mathrm{~N}_{2}$ were $81 \%$ and $81 \%$, respectively, which were significantly higher than those of other treatments. The germination index of $\mathrm{M}_{20} \mathrm{~N}_{1}$ and $\mathrm{M}_{40} \mathrm{~N}_{1}$ were $75 \%$ and $70 \%$, respectively, and those of $\mathrm{M}_{20} \mathrm{~N}_{2}$ and $\mathrm{M}_{40} \mathrm{~N}_{2}$ were $71.86 \%$ and $68.66 \%$, respectively. The germination index of these four tests was lower than those of the $\mathrm{M}_{0} \mathrm{~N}_{1}$ and $\mathrm{M}_{0} \mathrm{~N}_{2}$. The $\mathrm{M}_{0} \mathrm{~N}_{1}$ and $\mathrm{M}_{0} \mathrm{~N}_{2}$ groups, which showed the highest germination index, may provide more root growth and better promote the safety of plants [37]. 
Table 2. Biological parameters of weight changes of earthworms and germination index.

\begin{tabular}{ccccccc}
\hline Parameter $^{a}$ & \multicolumn{5}{c}{ Treatments } \\
\cline { 2 - 6 } & $\mathbf{M}_{\mathbf{0}} \mathbf{N}_{\mathbf{1}}$ & $\mathbf{M}_{\mathbf{0}} \mathbf{N}_{\mathbf{2}}$ & $\mathbf{M}_{\mathbf{2 0}} \mathbf{N}_{\mathbf{1}}$ & $\mathbf{M}_{\mathbf{4 0}} \mathbf{N}_{\mathbf{1}}$ & $\mathbf{M}_{\mathbf{2 0}} \mathbf{N}_{\mathbf{2}}$ & $\mathbf{M}_{\mathbf{4 0}} \mathbf{N}_{\mathbf{2}}$ \\
\hline $\begin{array}{c}\text { Weight changes of per } \\
\text { worm (g) }\end{array}$ & $0.16 \pm 0.02 \mathrm{a}$ & $0.11 \pm 0.02 \mathrm{ab}$ & $0.06 \pm 0.02 \mathrm{c}$ & $0.02 \pm 0.003 \mathrm{~d}$ & $0.05 \pm 0.05 \mathrm{bc}$ & $0.06 \pm 0.03 \mathrm{bc}$ \\
\hline Germination index (\%) & $81.07 \pm 1.35 \mathrm{a}$ & $81.13 \pm 4.95 \mathrm{a}$ & $75.64 \pm 7.74 \mathrm{a}$ & $70.16 \pm 5.63 \mathrm{a}$ & $71.86 \pm 4.20 \mathrm{a}$ & $68.66 \pm 8.97 \mathrm{a}$ \\
\hline
\end{tabular}

${ }^{\text {a }}$ For each parameter (see text for details), differences among treatments were determined by Tukey's test. Different letters in arrow are significant at $p<0.05$ (Tukey's test). ${ }^{\mathrm{b}}$ Weight changes of per worm between day 0 and the 60 th day.

\subsection{Correlation of Biological and Chemical Indexes}

According to the detrended correspondence analysis, the length of the gradient of the first axis was 0.961 , indicating that redundancy analysis (RDA) could better explain the relationship between the weight changes of per earthworm and germination index for environment factors compared with canonical correlation analysis. The ordination diagram based on RDA was presented (Figure 4). Similar trends were seen with the $M_{0} N_{1}$ and $M_{0} N_{2}$, which were highly positively correlated with earthworm weight change, germination index, $\mathrm{C} / \mathrm{N}$ ratio, organic matter, and $\mathrm{pH}$ value, but negatively correlated with TKN, TP, TK, and cellulose, which correlated positively with $\mathrm{M}_{20} \mathrm{~N}_{1}, \mathrm{M}_{40} \mathrm{~N}_{1}, \mathrm{M}_{20} \mathrm{~N}_{2}$, and $\mathrm{M}_{40} \mathrm{~N}_{2}$. In this study, earthworm weight change was positively correlated with germination index, and the relative seed germination recorded a higher range of earthworm weight gain [38]. The $\mathrm{C} / \mathrm{N}$ ratio, organic matter, and $\mathrm{pH}$ of the mixture had significant effects on the earthworms growth. The combination of $\mathrm{pH}$ value and organic matter had a significant effect on the mixture germination index.

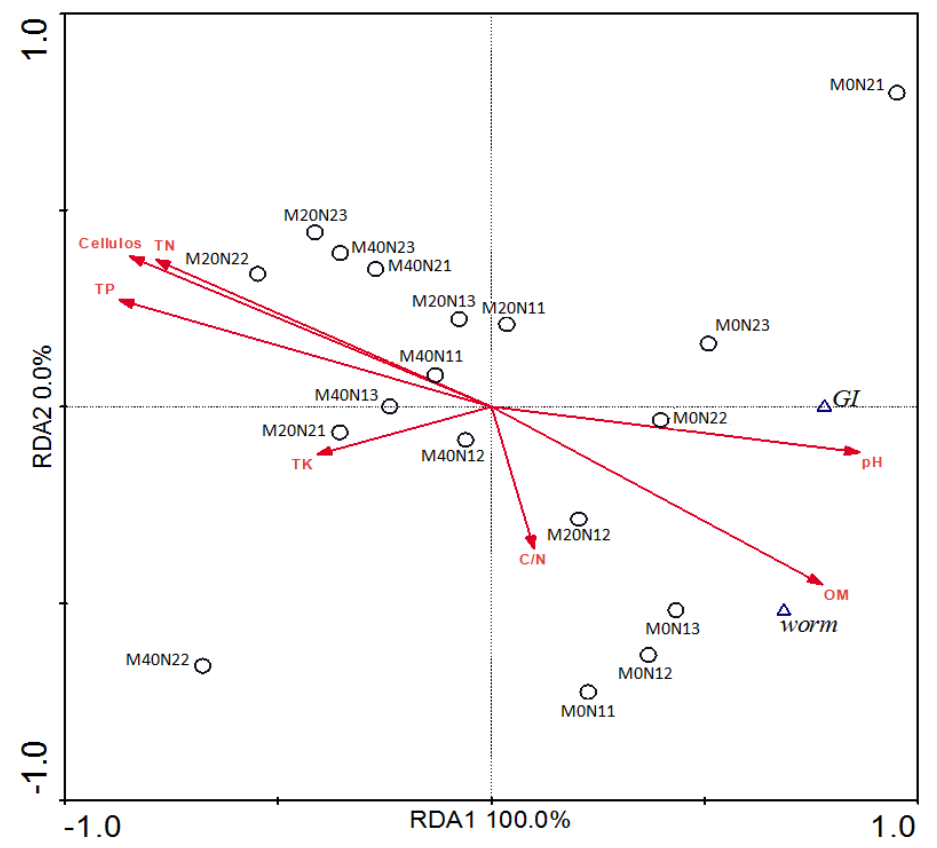

Figure 4. Redundancy analysis of the D_value of the weight of worms and germination rate to the environmental factors in the improved vermicomposting system (after 60 days).

\subsection{Composition of the Microbial Community}

The relative abundance of bacteria taxonomic groups were presented (Figure 5). Thirty bacteria phyla were identified. At the phylum level, in all groups, at day 0 , the dominant phyla were Proteobacteria, Bacteroidetes, Actinobacteria, and Firmicutes, which accounted for $99.8 \%$ of all bacteria. Proteobacteria was the most abundant phylum in all groups, followed 
by Bacteroidetes in groups $\mathrm{R}_{0}$ and $\mathrm{CK}_{0}$, indicating that when earthworms were not added, the bacteria in the mixture were mainly Proteobacteria and Bacteroidetes.

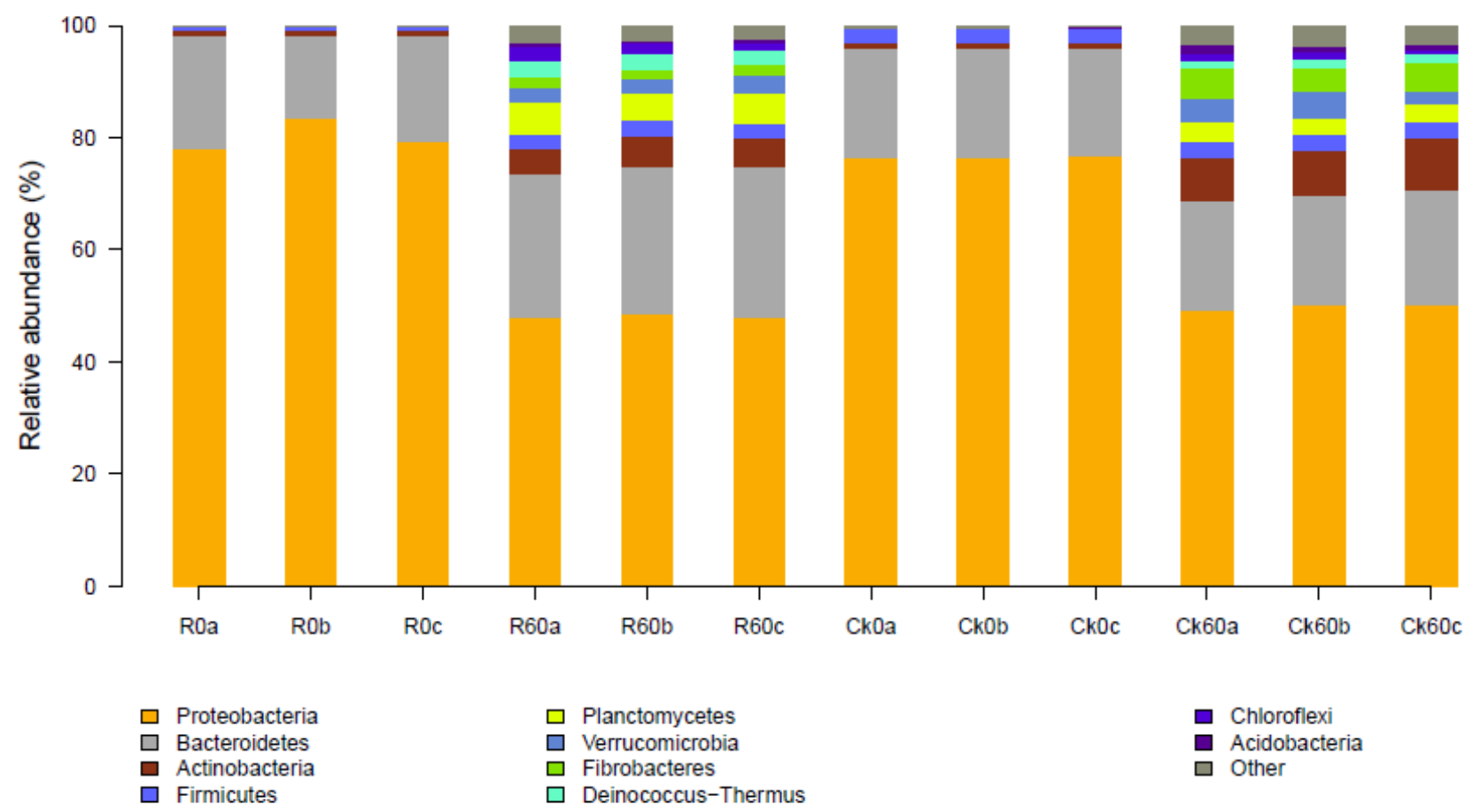

Figure 5. Composition of the bacterial communities at the phylum level. $R_{0 a}, R_{0 b}$, and $R_{0 c}$ : samples of the rice straw inoculated with earthworms, $R_{60 a}, R_{60 b}$, and $R_{60 c}$ : samples of the rice straw inoculated with earthworms after 60 days. $\mathrm{CK}_{0 \mathrm{a}}, \mathrm{CK}_{0 \mathrm{~b}}$, and $\mathrm{CK}_{0 \mathrm{c}}$ : samples of the rice straw without earthworms. $\mathrm{CK}_{60 \mathrm{a}}, \mathrm{CK}_{60 \mathrm{~b}}$, and $\mathrm{CK}_{60 \mathrm{c}}$ samples of the rice straw without earthworms after 60 days.

In groups $\mathrm{CK}$ and $\mathrm{R}$, at day 60 , the dominant phylum in the groups with earthworms were Proteobacteria and Bacteroidetes, the same as in the groups without earthworms, although the relative abundance of Proteobacteria decreased in both treatments, while the abundance of Bacteroidetes, Actinobacteria, Firmicutes, and Verrucomicrobia increased. The latter phyla have also been reported to dominate in compost studies without earthworms, which are generally involved in the degradation of organic waste [39]. Proteobacteria and Actinobacteria are lignin-degrading bacteria [40] while Bacteroidetes are thought to degrade cellulose and chitin [41]. Firmicutes produce celluloses, lipases, proteases, and other extracellular enzymes that degrade lignin, cellulose, sugars, and amino acids [42]. Finally, Verrucomicrobia is mainly found in lakes, drinking water, and other natural freshwater environments [43].

Original composting and vermicomposting modified the original microbial communities of the waste in diverse ways. The differences in microbiota patterns can be attributed to the physicochemical composition of the wastes and the interaction of the earthworms in the microbial communities [44]. Representative bacteria of mature compost (Actinobacteria) were more abundant in vermicomposting, and Bacteroidetes were more abundant in compost [45]. This resulted in the greater similarity of the microbial community structure between the products of natural placement and maturation via vermicomposting. This indicates that the microbial community composition was affected by the presence of earthworms and by the continuous addition of waste liquid.

\section{Conclusions}

In summary, the study presented here permits us to develop an improved vermicomposting system, in order to have efficient recycling of wastewater and reuse dairy wastewater, rice straw, and cow manure simultaneously. We demonstrated that earthworms could 
alter the biochemistry of dairy wastewater and other solid waste and accelerate the stabilization, maturity, and microbial community composition of organic waste. The $\mathrm{C} / \mathrm{N}$ ratio had the highest effects on earthworm growth, and the increase of earthworm weight promoted the mineralization of solid waste; also, the percentages of total nitrogen, phosphorous, and potassium increased, while organic matter content, $\mathrm{C} / \mathrm{N}$ ratio, and cellulose declined as a function of the vermicomposting period. For future experiments, we could proceed with the response of electrical conductivity and heavy metals during the vermicomposting period, and the effect of other agricultural organic wastes. This is a feasible method for the simultaneous disposal of organic wastes, especially in poor countries, because it incurs lower costs and has a lower impact on the environment. Our laboratory-scale experiment processing cow manure with earthworms might not fully duplicate large-scale commercial conditions, but provides valuable insights into the process and the changes brought about by earthworm activity.

Author Contributions: Data curation—formal analysis \& writing, X.L.; review, F.F.; funding acquisition, C.Z., B.G., L.L.; supervision, F.F., and C.Z. All authors have read and agreed to the published version of the manuscript.

Funding: This work was financially supported by National Water Pollution Control and Treatment Science and Technology Major Project in China (2017ZX07603002, 2015C03004), the National Science Foundation of Beijing (8182059).

Institutional Review Board Statement: Not applicable.

Informed Consent Statement: Not applicable.

Data Availability Statement: The data presented in this study are available on request from the corresponding author.

Acknowledgments: The authors would like to thank the University of Liège-Gembloux Agro-Bio Tech and more specifically Agriculture Is Life for the opportunity platform.

Conflicts of Interest: The authors declare no conflict of interest.

\section{References}

1. NDCC. The First National Census Atlas of Pollution Sources; China Surveying and Mapping Publishing House: Beijing, China, 2011; ISBN 978750302485. The first National Data Compilation Committee on pollution sources census.

2. Goncalves, M.R.; Costa, J.C.; Marques, I.P.; Alves, M.M. Strategies for lipids and phenolics degradation in the anaerobic treatment of olive mill wastewater. Water. Res. 2012, 46, 1684-1692. [CrossRef]

3. Haugen, F.; Bakke, R.; Lie, B.; Hovland, J.; Vasdal, K. Optimal design and operation of a UASB reactor for dairy cattle manure. Comput. Electron. Agr. 2015, 111, 203-213. [CrossRef]

4. Sergey, K.; Vyacheslav, F.; Alla, N. Anaerobic treatment of liquid fraction of hen manure in UASB reactors. Bioresour. Technol. 1998, 65, 221-225.

5. Daud, M.K.; Rizvi, H.; Akram, M.F.; Ali, S.; Rizwan, M.; Nafees, M.; Jin, Z.S. Review of upflow anaerobic sludge blanket reactor technology: Effect of different parameters and developments for domestic wastewater treatment. J. Chem. 2018, 2018, 1-13. [CrossRef]

6. Sebastian, B.; Jarosław, D.; Laurence, W. Anaerobic co-digestion of swine and poultry manure with municipal sewage sludge. Wast. Manag. 2014, 34, 513-521.

7. Zhang, W.Q.; Wei, Q.Y.; Wu, S.B.; Qi, D.D.; Li, W.; Zuo, Z.; Dong, R. Batch anaerobic co-digestion of pig manure with dewatered sewage sludge under mesophilic conditions. Appl. Energ. 2014, 128, 175-183. [CrossRef]

8. Su, L.L.; Lee, L.H.; Wu, T.Y. Sustainability of using composting and vermicomposting technologies for organic solid waste biotransformation: Recent overview, greenhouse gases emissions and economic analysis. J. Clean. Prod. 2016, 111, 262-278.

9. Zziwa, A.; Jjagwea, J.; Kizitob, S.; Kabengea, I.; Komakecha, A.J.; Kayondoa, H. Nutrient recovery from pineapple waste through controlled batch and continuous vermicomposting systems. J. Environ. Manag. 2021, 279, 111784. [CrossRef] [PubMed]

10. Sanchez-Hernandez, J.C.; Domínguez, J. Dual Role of Vermicomposting in Relation to Environmental Pollution. In Bioremediation of Agricultural Soils; CRC Press: Boca Raton, FL, USA, 2019; p. 217.

11. Rola, M.; Atiyeh, R.M.; Domínguez, J.; Subler, S.; Edwards, C.A. Changes in biochemical properties of cow manure during processing by earthworms (Eiseniaandrei, Bouché) and the effects on seedling growth. Pedobiologia 2000, 44, 709-724.

12. Lv, M.; Li, J.; Zhang, W.X.; Zhou, B.; Dai, J.; Zhang, C. Microbial activity was greater in soils added with herb residue vermicompost than chemical fertilizer. Ecol. Lett. 2020, 2, 209-219. [CrossRef] 
13. Sinha, R.K.; Agarwal, S.; Chauhan, K.; Valani, D. The wonders of earthworms \& its vermicompost in farm production: Charles Darwin's friends of farmers, with potential to replace destructive chemical fertilizers from agriculture. Agr. Sci. 2010, 1, 76-97.

14. Patwa, A.; Parde, D.; Dohare, D.; Vijay, R.; Kumar, R. Solid waste characterization and treatment technologies in rural areas: An Indian and international review. Environ. Technol. Innov. 2020, 20, 101066. [CrossRef]

15. Taylor, M.; Clarke, W.P.; Greenfield, P.F. The treatment of domestic wastewater using small scale vermicompost filter beds. Ecol. Eng. 2003, 21, 197-203. [CrossRef]

16. Haimi, J.; Huhta, V. Comparison of composts produced from identical wastes by "vermistabilization" and conventional composting. Pedobiologia 1987, 30, 137-144.

17. Kalembasa, S.J.; Jenkinson, D.S. A Comparative study of titrimetric and gravimetric methods for the determination of organic carbon in soil. Sci. Food. Agri. 1973, 24, 1085-1090. [CrossRef]

18. Jackson, M.L. Soil Chemical Analysis; Prentice Hall of India Pvt. Ltd.: New Delhi, India, 1973.

19. Crosland, A.R.; Zhao, F.J.; McGrath, S.P.; Lane, P.W. Comparison of aqua regia digestion with sodium carbonate fusion for the determination of total phosphorus in soil by inductively coupled plasma atomic emission spectroscopy (ICP). Commun. Soil Sci. Plan. 1995, 26, 1357-1368. [CrossRef]

20. Awasthi, M.K.; Pandey, A.K.; Khan, J.; Bundela, P.S.; Wong, J.W.C.; Selvam, A. Evaluation of thermophilic fungal consortium for organic municipal solid waste composting. Bioresour. Technol. 2014, 168, 214-221. [CrossRef]

21. Zhang, L.; Sun, X.Y. Changes in physical, chemical, and microbiological properties during the two-stage co-composting of green waste with spent mushroom compost and biochar. Bioresour. Technol. 2014, 171, 274-284. [CrossRef]

22. Datta, S.; Singh, J.; Singh, S.; Singh, J. Earthworms, pesticides and sustainable agriculture: A review. Environ. Sci. Pollut. R. 2016, 23, 8227-8243. [CrossRef]

23. Deka, R.; Kumar, R.; Tamuli, R. Neurospora crassa homologue of neuronal calcium sensor-1 has a role in growth, calcium stress tolerance, and ultraviolet survival. Genetica 2011, 139, 885-894. [CrossRef]

24. Partanen, P.; Hultman, J.; Paulin, L.; Auvinen, P.; Romantschuk, M. Bacterial diversity at different stages of the composting process. BMC Microbiol. 2010, 10, 1-11. [CrossRef]

25. Gu, W.J.; Zhang, F.B.; Xu, P.Z.; Tang, S.H.; Xie, K.Z.; Huang, X.; Huang, Q.Y. Effects of sulphur and Thiobacillus thioparus on cow manure aerobic composting. Bioresour. Technol. 2011, 102, 6529-6535. [CrossRef]

26. Li, Y.K.; Yang, X.L.; Gao, W.; Qiu, J.P.; Li, Y.S. Comparative study of vermicomposting of garden waste and cow dung using Eisenia fetida. Environ. Sci. Pollut. Res. 2020, 27, 9646-9657. [CrossRef]

27. Elvira, C.; Sampedro, L.; Benitez, E.; Nogales, R. Bioconversion of solid paper-pulp mill sludge by earthworms. Bioresour. Technol. 1998, 57, 173-177. [CrossRef]

28. Ndegwa, P.M.; Thompson, S.A. Integrating composting and vermicomposting in the treatment and bioconversion of biosolids. Bioresour. Technol. 2001, 76, 107-112. [CrossRef]

29. Bernal, M.P.; Paredes, C.; Sanchez-Monedero, M.A.; Cegarra, J. Maturity and stability parameters of composts prepared with a wide range of organic waste. Bioresour. Technol. 1998, 63, 91-99. [CrossRef]

30. Bordna Mona. Compost Testing and Analysis Service - Interpretation of Results; Bordna Mona, Newbridge, Co.: Kildare, Ireland, 2003.

31. NY 525-2012. People's Republic of China Agricultural Industry Standard; China Agricultural Publishing House: Beijing, China.

32. El-Haddad, M.E.; Zayed, M.S.; El-Sayed, G.A.M.; Hassanein, M.K.; El-Satar, A.M.A. Evaluation of compost, vermicompost and their teas produced from rice straw as affected by addition of different supplements. Ann. Ggr. Sci. 2014, 59, 243-251. [CrossRef]

33. Aira, M.; Monroy, F.; Domínguez, J. C to N ratio strongly affects population structure of Eisenia fetida in vermicomposting systems. Eur. J. Soil Biol. 2006, 42, S127-S131. [CrossRef]

34. Garg, P.; Gupta, A.; Satya, S. Vermicomposting of different types of waste using Eisenia foetida: A comparatives study. Bioresour. Technol. 2006, 97, 391-395. [CrossRef]

35. Venkatesh, R.M.; Eevera, T. Mass reduction and recovery of nutrients through vermicomposting of fly ash. Appl. Ecol. Env. Res. 2008, 6, 77-84. [CrossRef]

36. Zucconi, F.; Pera, A.; Forte, M.; Bertoldi, M.D. Evaluating toxicity of immature compost. Biocycle 1981, $22,54-57$.

37. Bajsa, O.; Nair, J.; Mathew, K.; Ho, G. Vermiculture as a tool for domestic wastewater management. Water. Sci. Technol. 2003, 48, 125-132. [CrossRef]

38. Ravindran, B.; Contreras-Ramos, S.M.; Wong, J.W.C.; Selvam, A.; Sekaran, G. Nutrient and enzymatic changes of hydrolysed tannery solid waste treated with epigeic earthworm Eudrilus eugeniae and phytotoxicity assessment on selected commercial crops. Environ. Sci. Pollut. Res. 2014, 21, 641-651. [CrossRef] [PubMed]

39. Wang, X.J.; Pan, S.Q.; Zhang, Z.Z.; Lin, X.Y.; Zhang, Y.Z.; Chen, S.H. Effects of the feeding ratio of food waste on fed-batch aerobic composting and its microbial community. Bioresour. Technol. 2017, 224, 397-404. [CrossRef]

40. Bugg, T.D.; Ahmad, M.; Hardiman, E.M.; Singh, R. The emerging role for bacteria in lignin degradation and bio-product formation. Curr. Opin. Biotech. 2011, 22, 394-400. [CrossRef] [PubMed]

41. Manz, W.; Amann, R.; Ludwig, W.; Vancanneyt, M.; Schleifer, K.-H. Application of a suite of 16S rRNA-specific oligonucleotide probes designed to investigate bacteria of the phylum cytophaga-flavobacter-bacteroides in the natural environment. Microbiology 1996, 142, 1097-1106. [CrossRef] [PubMed]

42. Lim, J.W.; Chiam, J.A.; Wang, J.Y. Microbial community structure reveals how micro aeration improves fermentation during anaerobic co-digestion of brown water and food waste. Bioresour. Technol. 2014, 171, 132-138. [CrossRef] 
43. Zwart, G.; Crump, B.C.; Kamst-van Agterveld, M.P.; Hagen, F.; Han, S.K. Typical freshwater bacteria: An analysis of avail-able $16 \mathrm{~S}$ rRNA gene sequences from plankton of lakes and rivers. Aquat. Microb. Ecol. 2002, 28, 141-155. [CrossRef]

44. Villar, I.; Alves, D.; Pérez-Díaz, D.; Mato, S. Changes in microbial dynamics during vermicomposting of fresh and composted sewage sludge. Wast. Manag. 2016, 48, 409-417. [CrossRef]

45. Danon, M.; Franke-Whittle, I.H.; Insam, H.; Chen, Y.; Hadar, Y. Molecular analysis of bacterial community succession during prolonged compost curing. Fems. Microbiol. Ecol. 2008, 65, 133-144. [CrossRef] 